\title{
A qualitative systematic review of the social eating and drinking experiences of patients following treatment for head and neck cancer
}

\author{
Mark Dornan $^{1}$ (D) $\cdot$ Cherith Semple ${ }^{1,2}$ (D) Anne Moorhead $^{3}$ (D) Eilís McCaughan ${ }^{4}$
}

Received: 1 January 2021 / Accepted: 7 February 2021 / Published online: 1 March 2021

(C) Crown 2021

\begin{abstract}
Purpose Patients living with and beyond head and neck cancer (HNC) often have long-term, functional challenges as a result of treatment. A key functional challenge relates to eating and drinking; often associated with physical, emotional, and social difficulties. Eating and drinking with family members and friends can become a struggle, increasing the risk of social isolation and loneliness. This systematic review aims to identify and synthesise the literature on the experiences of social eating and drinking for patients following treatment for HNC.

Methods Six electronic databases (Pubmed, Web of Science, CINAHL, EMBASE, PsychINFO, and Scopus) were systematically searched using subject headings and free-text word searches in February 2020. Citation chaining and Google Scholar were used to identify grey literature. PRISMA procedures were followed.

Results Of 6910 records identified, 24 studies met the inclusion criteria. Synthesis of the research findings results in two major themes: (1) the experience of loss associated with social eating and drinking, and (2) adjusting and support to promote social eating and drinking.

Conclusion Losses associated with social eating affect a patient's psychological and emotional well-being and impact on close relationships. To promote positive participation in social eating, patients were more likely to seek and receive support from someone within their close social network, rather than a healthcare professional. Family and friends are an essential source of support and are integral in facilitating engagement with social eating following treatment for HNC. Future interventions should promote family orientated resources, incorporating self-management strategies.
\end{abstract}

Keywords Head and neck cancer $\cdot$ Cancer survivorship $\cdot$ Eating $\cdot$ Social $\cdot$ Systematic review

\section{Introduction}

The concept of social eating and drinking is to eat or drink in the presence of another person [1]. Eating and drinking socially is also known as commensality, which in a literal sense means to come together at a table $[2,3]$. Social eating may

Mark Dornan

dornan-d@ulster.ac.uk

1 School of Nursing, Institute of Nursing and Health Research, Ulster University, Newtownabbey, UK

2 Cancer Services and Ulster Hospital, South Eastern Health and Social Care Trust, Belfast, UK

3 School of Communication and Media, Institute of Nursing and Health Research, Ulster University, Newtownabbey, UK

4 School of Nursing, Institute of Nursing and Health Research, Ulster University, Coleraine, UK take place as a daily activity, with most people eating at least one or two meals with another person each day, primarily, those with whom they live [4, 5]. Eating with colleagues or going to cafés and restaurants to meet friends has become a regular aspect of modern life and an opportunity to bring people together. Social eating and drinking are observed as integral aspects of cultural, religious, and celebratory occasions [6-8].

Literatures illustrate that eating and drinking have a central and significant meaning to peoples' lives [6]. Eating and drinking are observed and enjoyed as more than a physical activity, and its meaning extends beyond the value of nutrition [9]. Sharing meals with others provides the opportunity to engage in everyday casual conversation and to share experiences [6]. Eating socially nurtures relationships and is more likely to make people feel better about themselves, participate in a broader social network and obtain emotional support [4]. 
For patients with head and neck cancer (HNC), eating and drinking with others are reported as a significant challenge [10]. Research reports that up to $90 \%$ of patients with HNC have eating and drinking difficulties after treatment $[11,12]$. A potential range of side effects can inhibit a patient's ability to eat and drink, including pain, xerostomia, mucositis, nausea, lack of appetite, dysphagia, and dysgeusia [11, 13].

A growing body of evidence indicates the challenges of social eating and drinking for patients with $\mathrm{HNC}[14,15]$. A literature review by Ganzer et al. [14] on the changed meaning of food identified the importance of the social dimension of food and drink for patients with HNC. Patients with HNC are at potential risk of social isolation, loneliness, and reduced quality of life from the functional eating and drinking difficulties encountered as a result of treatment [15]. There have been no systematic searches or literature syntheses on the experiences of social eating and drinking for patients with HNC. This is a fundamental gap in our current understanding of the survivorship experiences of patients living with and beyond $\mathrm{HNC}$.

A systematic synthesis of the literature will establish opportunities to raise healthcare professionals' (HCP) awareness and inform them of the long-term social eating and drinking adversities encountered by patients with HNC. Furthermore, this review will help identify and consolidate the key areas of support and inform the planning, development, and delivery of evidence-based support to address these challenges. Therefore, the aim of this review is to identify and synthesise the experiences of social eating and drinking of patients living with and beyond HNC. The objectives of this systematic review are:

- To explore the social experiences of eating and drinking of patients following treatment for $\mathrm{HNC}$.

- To identify the support needs surrounding social eating and drinking for patients following treatment for HNC.

- To identify strategies to promote social eating and drinking for patients following treatment for $\mathrm{HNC}$.

\section{Methods}

The systematic review followed an a priori protocol adhering to the Preferred Reporting Items for Systematic Reviews and Meta-analyses (PRISMA) [16] (Electronic Supplementary Material 1). The systematic review protocol was registered on with the International Prospective Register of Systematic Reviews (PROSPERO) with registration number CRD42020162875.

\section{Search strategy}

Six electronic databases were used to identify relevant literature: Pubmed, Web of Science, Cumulative Index of Nursing and Health (CINAHL), Excerpta Medica Database (EMBASE), PsycINFO, and Scopus. The search terms were developed from the key concepts of the review aim: 'head and neck cancer', 'eating and drinking challenges', and 'experiences'. Free-text word searches and subject heading searches were used as appropriate to each database to ensure a comprehensive search. The final list of terms was clarified with an experienced librarian, confirming a systematic approach was undertaken between different databases. Grey literature was reviewed from Google Scholar to ensure complete coverage. Citation chaining was used to identify eligible works from the references of the included studies. 'Wildcards' were also used to search for partial words, alternative spellings, and pluralisation. All searches were completed on 17 February 2020. The database searches are displayed in Electronic Supplementary Material 2. All results were collated in RefWorks.

\section{Study eligibility}

Study inclusion criteria consisted of (1) patients aged 18 years and over who had completed treatment for HNC, (2) research described a patient's experience of social eating and drinking, (3) the publication was primary research. Studies were excluded as follows: (1) secondary research (e.g. reviews, opinion articles, editorials), (2) papers reporting on the physical and functional impact of HNC only without reporting the social experiences of eating and drinking relating to HNC, (3) studies that report on more than one type of cancer, where findings cannot be separated to results of an HNC cancer group. Retrieved studies were published in English from January 2009 to December 2019 to obtain current evidence on this survivorship challenge for patients with HNC.

\section{Screening}

Duplicates were removed. Titles and abstracts were reviewed using the eligibility criteria by one reviewer (MD). This process was checked by a second reviewer (CS). Full-text papers were obtained for studies meeting the eligibility criteria or if the eligibility could not be determined from the title and abstract screen. Two authors were contacted for clarification of their work. Full-text papers were screened using a screening tool developed by the research team to assess eligibility and to ensure rigour (Electronic Supplementary Material 3). Included papers were verified by $\mathrm{CS}$, and a decision on indeterminate studies was reached by discussion with CS. This process is displayed in Fig. 1. 
Fig. 1 PRISMA flowchart

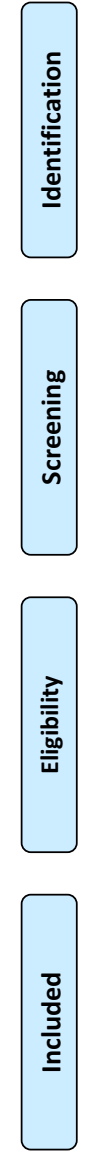

Records identified through database searching $(\mathrm{n}=6905)$
Additional records identified through other sources $(n=6)$

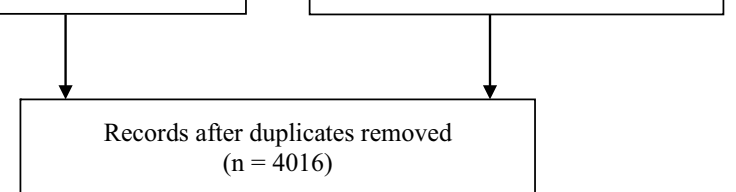

$(\mathrm{n}=4016)$

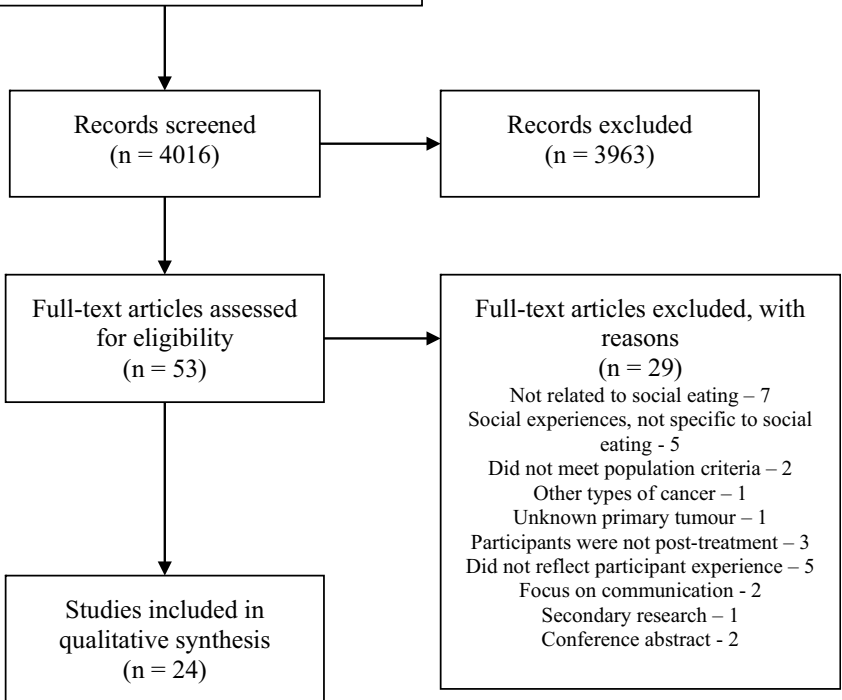

CS. The CASP tool is a commonly used method to appraise studies in qualitative synthesis and consider research transparency and methodological appropriateness [43]. Each response in the CASP tool was assigned a numerical value (Yes=1, Can't tell $=0, \mathrm{No}=0$ ). A total score was then calculated for each included study with a maximum possible score of 9. A summary table is included in Electronic Supplementary Material 4. Any differences of opinion were resolved by discussion.

\section{Results}

The search identified 6905 records (Pubmed $(n=1091)$, Scopus $(n=1437)$, PsycINFO $(n=57)$, CINAHL $(n=631)$, Web of Science $(n=1373)$, EMBASE $(n=2316))$ with 4015 remaining after the removal of duplicates. In total, 53 titles met the eligibility criteria to have a full-text screen. Subsequently, and after a further screening, 25 articles were excluded. Four further papers were later discussed with CS and on agreement, subsequently eliminated from the final inclusion as they did not meet the eligibility criteria. The final total number of papers included was 24. A member of the research team verified each included study. A record of the decision to include and exclude papers with reason was kept. Reasons for exclusion are included in Fig. 1. All the included 
Table 1 Data extraction table

\begin{tabular}{|c|c|c|c|c|c|}
\hline $\begin{array}{l}\text { Author(s), year } \\
\text { and country }\end{array}$ & Study aim & $\begin{array}{l}\text { Research } \\
\text { design }\end{array}$ & Data collection & Sample characteristics & Main study findings \\
\hline $\begin{array}{l}\text { Alberda et al. } \\
\quad(2017)[17] \\
\text { Canada }\end{array}$ & $\begin{array}{l}\text { To explore patients' } \\
\text { perspectives on nutrition } \\
\text { care in the context of their } \\
\text { illness, medical treatment, } \\
\text { and recovery }\end{array}$ & Qualitative & $\begin{array}{l}\text { Semi-structured } \\
\text { interview }\end{array}$ & $\begin{array}{l}20 \text { participants, } 10 \text { with } \\
\text { oesophageal cancer ( } 8 \text { male and } \\
2 \text { female) } 10 \text { with HNC ( } 8 \text { male } \\
\text { and } 2 \text { female). Age range } 45-79 \\
\text { years. } \\
\text { Treatment: surgery only-1; RT } \\
\text { only-1; surgery/RT/CT-12; } \\
\text { surgery/RT-6. }\end{array}$ & $\begin{array}{l}\text { (1) Coping with physical and } \\
\text { psychosocial aspects of illness } \\
\text { and nutrition; (2) understanding } \\
\text { the nature of the illness, } \\
\text { treatment, and nutrition pathway; } \\
\text { and (3) being supported during } \\
\text { the trajectory of care. }\end{array}$ \\
\hline $\begin{array}{l}\text { Burges-Watson } \\
\text { et al. (2018) } \\
\text { [18] } \\
\text { England, UK }\end{array}$ & $\begin{array}{l}\text { To create a multi-dimensional } \\
\text { framework to facilitate } \\
\text { systematic assessment and } \\
\text { development of a } \\
\text { comprehensive intervention }\end{array}$ & Qualitative & $\begin{array}{l}\text { Video-reflexive } \\
\text { ethnography }\end{array}$ & $\begin{array}{l}25 \text { participants with } \mathrm{HNC} \text { (14 male } \\
\text { and } 11 \text { female) and partners. Age } \\
\text { range } 54-65 \text {. Treatment: } \\
\text { (chemo)radiotherapy-25. }\end{array}$ & $\begin{array}{l}\text { The development of an altered } \\
\text { eating framework to assess a } \\
\text { patient's relationship with food } \\
\text { over } 7 \text { domains after treatment } \\
\text { for HNC. }\end{array}$ \\
\hline $\begin{array}{l}\text { Checklin et al. } \\
\qquad(2019)[19] \\
\text { Australia }\end{array}$ & $\begin{array}{l}\text { To investigate patients' } \\
\text { perspectives on their } \\
\text { experience of } \\
\text { oropharyngeal dysphagia } \\
\text { rehabilitation after } \\
\text { treatment for HNC }\end{array}$ & Qualitative & $\begin{array}{l}\text { Semi-structured } \\
\text { in-depth } \\
\text { interview }\end{array}$ & $\begin{array}{l}8 \text { participants with HNC ( } 6 \text { male } \\
\text { and } 2 \text { female). Age range } 51-75 \\
\text { years. Treatment: surgery only- } \\
\text { 7; surgery and RT-1. }\end{array}$ & $\begin{array}{l}\text { (1) The supportive network is } \\
\text { essential; (2) reassurance from } \\
\text { staff professionalism; (3) access } \\
\text { to service; (4) using own } \\
\text { motivation and resilience; (5) } \\
\text { receiving the right information; } \\
\text { (6) need for future research. }\end{array}$ \\
\hline $\begin{array}{l}\text { Dooks et al. } \\
\quad(2012)[20] \\
\text { Canada }\end{array}$ & $\begin{array}{l}\text { To describe the experience of } \\
\text { community reintegration } \\
\text { following laryngectomy } \\
\text { surgery }\end{array}$ & Qualitative & $\begin{array}{l}\text { In-depth } \\
\text { interview }\end{array}$ & $\begin{array}{l}9 \text { participants who had total } \\
\text { laryngectomy surgery ( } 8 \text { male } \\
\text { and } 1 \text { female). Age range } 60-75 \\
\text { years. Treatment: total } \\
\text { laryngectomy surgery and RT- } \\
9 .\end{array}$ & $\begin{array}{l}\text { There was constant accommodation } \\
\text { to life with a laryngectomy. } \\
\text { Three main themes: (1) impact of } \\
\text { cancer diagnosis; (2) coping with } \\
\text { illness; and (3) transitions to } \\
\text { recovery. }\end{array}$ \\
\hline $\begin{array}{l}\text { Dunne et al. } \\
\qquad(2019)[21] \\
\text { Ireland }\end{array}$ & $\begin{array}{l}\text { To describe the ways in which } \\
\text { HNC survivors begin to } \\
\text { integrate self-management } \\
\text { into their daily lives }\end{array}$ & Qualitative & $\begin{array}{l}\text { Semi-structured } \\
\text { interview }\end{array}$ & $\begin{array}{l}27 \text { participants with HNC (18 male } \\
\text { and } 9 \text { female). Age range } 25-70+ \\
\text { years. Treatment: surgery and } \\
\text { RT-10; surgery, RT and CT- } \\
\text { 11; RT and CT-6. }\end{array}$ & $\begin{array}{l}\text { (1) Grappling with } \\
\text { self-management; (2) trying } \\
\text { different strategies; (3) becoming } \\
\text { an expert; (4) struggles; (5) } \\
\text { avoiding recommendations; and } \\
\text { (6) interpreting } \\
\text { self-management. }\end{array}$ \\
\hline $\begin{array}{l}\text { Einarsson et al. } \\
\quad(2019)[22] \\
\text { Sweden }\end{array}$ & $\begin{array}{l}\text { To describe patients' } \\
\text { experiences of food and } \\
\text { eating } 2 \text { years after } \\
\text { treatment and how they } \\
\text { cope }\end{array}$ & Qualitative & $\begin{array}{c}\text { Thematically } \\
\text { structured } \\
\text { interview }\end{array}$ & $\begin{array}{l}135 \text { patients with HNC (100 male } \\
\text { and } 35 \text { female). Age range 34-87 } \\
\text { years. Treatment: RT - 49; } \\
\text { surgery-4; RT then surgery- } \\
\text { 34; surgery then RT-29; CT, } \\
\text { RT, and/or surgery_-19. }\end{array}$ & $\begin{array}{l}\text { (1) The constant battle; (2) food } \\
\text { alterations and nutritional } \\
\text { support; (3) not joining in; (4) } \\
\text { coping; (5) relationships; and (6) } \\
\text { longing for 'normality'. }\end{array}$ \\
\hline $\begin{array}{l}\text { Ganzer et al. } \\
\quad(2015)[23] \\
\text { USA }\end{array}$ & $\begin{array}{l}\text { To explore the eating } \\
\text { experience of survivors of } \\
\text { HNC up to } 3 \text { years after } \\
\text { chemoradiation }\end{array}$ & Mixed methods & $\begin{array}{l}\text { Interview and } \\
\text { Vanderbilt } \\
\text { Head and } \\
\text { Neck } \\
\text { Symptom } \\
\text { Survey } 2.0\end{array}$ & $\begin{array}{l}10 \text { patients with } \mathrm{HNC} \text { ( } 7 \text { male and } 3 \\
\text { female). Age range } 40-67 \text { years. } \\
\text { Treatment: induction CT-7; } \\
\text { concurrent chemoradiation } \\
\text { (CCR) therapy only-1; CCR } \\
\text { and surgery-2; induction CT, } \\
\text { CCR, surgery-3; concurrent } \\
\text { chemotherapy-10. }\end{array}$ & $\begin{array}{l}\text { (1) The psychological impact; (2) } \\
\text { functional impact; (3) social } \\
\text { impact; and (4) eating } \\
\text { experience. These were } \\
\text { encompassed by the overarching } \\
\text { need to adapt. }\end{array}$ \\
\hline $\begin{array}{l}\text { Goswami and } \\
\quad \text { Gupta (2019) } \\
{[24]} \\
\text { India }\end{array}$ & $\begin{array}{l}\text { To understand the problems } \\
\text { faced by patients with oral } \\
\text { cancer from diagnosis until } \\
\text { end of treatment }\end{array}$ & Qualitative & $\begin{array}{l}\text { In-depth } \\
\text { interview }\end{array}$ & $\begin{array}{l}24 \text { patients with HNC (18 male and } \\
6 \text { female). Age range } 35-82 . \\
\text { Treatment: Surgery and RT-8; } \\
\text { surgery, RT, and CT-7; } \\
\text { surgery, RT, and PL-2; RT, } \\
\text { CT, and PL-2; surgery, RT, } \\
\text { CT, and PL-5. }\end{array}$ & $\begin{array}{l}\text { Post treatment challenges included: } \\
\text { (1) concerns for quality of life; } \\
\text { (2) social constraints; (3) } \\
\text { financial security; and (4) } \\
\text { feeding problem. }\end{array}$ \\
\hline $\begin{array}{l}\text { Jiang et al. } \\
\quad(2017)[25] \\
\text { China }\end{array}$ & $\begin{array}{l}\text { To describe the experience of } \\
\text { radiation-induced } \\
\text { xerostomia in the daily lives } \\
\text { of Chinese patients with } \\
\text { HNC }\end{array}$ & Qualitative & $\begin{array}{l}\text { Semi-structured } \\
\text { interview }\end{array}$ & $\begin{array}{l}20 \text { patients with HNC ( } 13 \text { male and } \\
7 \text { female). Age range } 29-80 \\
\text { years. Treatment: RT and } \\
\text { adjuvant CT-6; RT only-5; } \\
\text { concurrent CT-5; RT and } \\
\text { surgery-2; surgery, CT, and } \\
\text { RT-2. }\end{array}$ & $\begin{array}{l}\text { Five categories identified in relation } \\
\text { to xerostomia from HNC } \\
\text { treatment: (1) communication } \\
\text { problems; (2) physical problems; } \\
\text { (3) psychosocial problems; (4) } \\
\text { treatment problems; and (5) relief } \\
\text { strategies. }\end{array}$ \\
\hline $\begin{array}{l}\text { McQuestion } \\
\text { et al. (2011) } \\
\text { [26] }\end{array}$ & $\begin{array}{l}\text { To explore the experiences of } \\
\text { patients' receiving } \\
\text { radiotherapy and the }\end{array}$ & Qualitative & Interview & $\begin{array}{l}17 \text { patients with } \mathrm{HNC} \text { ( } 12 \text { male and } \\
5 \text { female). Age range } 30-70+ \\
\text { years. Treatment: Daily RT-17; }\end{array}$ & $\begin{array}{l}\text { The meaning of food had changed } \\
\text { and was evident in three aspects }\end{array}$ \\
\hline
\end{tabular}


Table 1 (continued)

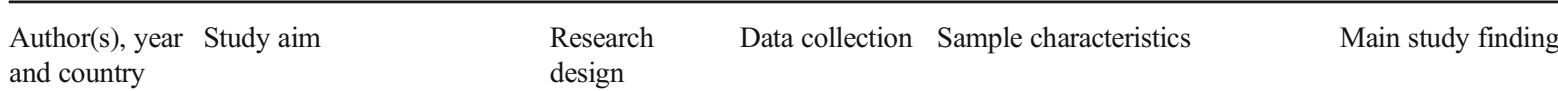

and country design

\begin{tabular}{|c|c|c|c|c|c|}
\hline Canada & $\begin{array}{l}\text { disruptions caused by } \\
\text { treatment }\end{array}$ & & & BID radiation -5 . & $\begin{array}{l}\text { of people's lives: (1) physical; (2) } \\
\text { emotional; (3) social. }\end{array}$ \\
\hline $\begin{array}{l}\text { Molassiotis and } \\
\text { Rogers } \\
\text { (2012) [27] }\end{array}$ & $\begin{array}{l}\text { To explore experiences, over a } \\
1 \text {-year period, of issues and } \\
\text { concerns described by }\end{array}$ & Qualitative & $\begin{array}{l}\text { Semi-structured } \\
\text { interview }\end{array}$ & $\begin{array}{l}16 \text { patients at } \mathrm{T} 1 \text { (14 male and } 2 \\
\text { female), } 13 \text { at } \mathrm{T} 2,12 \text { at T3, and } \\
10 \text { at } \mathrm{T} 4 \text { with } \mathrm{HNC} \text {. Age range }\end{array}$ & $\begin{array}{l}\text { Four prominent issues reported up } \\
\text { to } 1 \text { year by patients: (1) } \\
\text { nutritional concerns; (2) }\end{array}$ \\
\hline England & patients with $\mathrm{HNC}$ & & & $\begin{array}{l}\text { 34-80 years. Treatment: RT }-8 \text {; } \\
\text { CT and RT }-4 \text {; surgery }-4 \text {. }\end{array}$ & $\begin{array}{l}\text { tiredness; }(3) \text { the radiotherapy } \\
\text { mask; (4) regaining 'normality’. }\end{array}$ \\
\hline $\begin{array}{l}\text { Moore et al. } \\
\quad(2014)[28] \\
\text { Australia }\end{array}$ & $\begin{array}{l}\text { To explore the experiences of } \\
\text { patients who received } \\
\text { treatment for HNC, } \\
\text { describe support needs and } \\
\text { managing unmet needs }\end{array}$ & Qualitative & $\begin{array}{l}\text { Semi-structured } \\
\text { interview }\end{array}$ & $\begin{array}{c}8 \text { patients with } \mathrm{HNC} \text { ( } 7 \text { male and } 1 \\
\text { female). Age range } 51-60 \text { years. } \\
\text { Treatment: CT-3; surgery and } \\
\text { RT-2; surgery, RT, and CT-3. }\end{array}$ & $\begin{array}{l}\text { Findings were organised using the } \\
\text { stress, appraisal, and coping } \\
\text { model and describe the areas for } \\
\text { support and the negative impact } \\
\text { on quality of life post-treatment. }\end{array}$ \\
\hline $\begin{array}{l}\text { Mortensen and } \\
\text { Paaske } \\
\text { (2012) [29] } \\
\text { Denmark }\end{array}$ & $\begin{array}{l}\text { To explore the long-term } \\
\text { quality of life of people who } \\
\text { have tonsil cancer }\end{array}$ & Qualitative & $\begin{array}{l}\text { Semi-structured } \\
\text { interview }\end{array}$ & $\begin{array}{l}7 \text { patients with tonsil cancer ( } 3 \text { male } \\
\text { and } 4 \text { female). Age range 54-65 } \\
\text { years. Treatment: RT and } \\
\text { surgery }-4, \text { RT, CT, and } \\
\text { surgery-3. }\end{array}$ & $\begin{array}{l}\text { The side effect of treatment was } \\
\text { greatest at } 3 \text { months after } \\
\text { treatment. People reported } \\
\text { impact on QoL even } 2 \text { years after } \\
\text { treatment. }\end{array}$ \\
\hline $\begin{array}{l}\text { Nund et al. (A) } \\
\text { (2014) [30] } \\
\text { Australia }\end{array}$ & $\begin{array}{l}\text { To explore the lived } \\
\text { experience of the impact of } \\
\text { dysphagia following HNC } \\
\text { management }\end{array}$ & Qualitative & Interview & $\begin{array}{l}24 \text { patients with HNC ( } 20 \text { male and } \\
4 \text { female). Age range } 43-71 \\
\text { years. Treatment: RT }+ \text { systemic } \\
\text { therapy-23; RT only- } 1 \text {. }\end{array}$ & $\begin{array}{l}\text { Four main themes of the experience } \\
\text { of dysphagia following } \\
\text { treatment: (1) physical changes; } \\
\text { (2) emotions response; (3) altered } \\
\text { meaning of food; (4) personal } \\
\text { and lifestyle impacts. }\end{array}$ \\
\hline $\begin{array}{l}\text { Nund et al. (B) } \\
\quad \text { (2014) [31] } \\
\text { Australia }\end{array}$ & $\begin{array}{l}\text { To explore the experience of } \\
\text { dysphagia following } \\
\text { non-surgical treatment for } \\
\text { HNC the perceptions of } \\
\text { service needs }\end{array}$ & Qualitative & Interview & $\begin{array}{l}24 \text { patients with HNC ( } 20 \text { male and } \\
4 \text { female). Age range } 43-71 \\
\text { years. Treatment: RT }+ \text { systemic } \\
\text { therapy-23; RT only- }-1\end{array}$ & $\begin{array}{l}\text { There are five interrelated themes to } \\
\text { this study: (1) life after treatment; } \\
\text { (2) practical adjustments living } \\
\text { with dysphagia; (3) emotional } \\
\text { adjustments; (4) accessing } \\
\text { support outside the hospital; and } \\
\text { (5) perceptions of } \\
\text { dysphagia-related services. }\end{array}$ \\
\hline $\begin{array}{l}\text { O'Brien et al. } \\
\text { (2012) [32] } \\
\text { Ireland }\end{array}$ & $\begin{array}{l}\text { To explore the experiences of } \\
\text { change within intimate } \\
\text { relationships due to HNC }\end{array}$ & Qualitative & $\begin{array}{l}\text { Semi-structured } \\
\text { interview }\end{array}$ & $\begin{array}{l}16 \text { patients with HNC (12 male and } \\
4 \text { female). Age range } 35-71 . \\
\text { Treatment: surgery only-5; } \\
\text { surgery + RT-8; surgery + } \\
\text { chemo-radiotherapy-1; } \\
\text { chemo-radiotherapy }-2 \text {. }\end{array}$ & $\begin{array}{l}\text { Three major themes demonstrate } \\
\text { the changes in intimacy of } \\
\text { relationships following } \\
\text { treatment: (1) personal identity; } \\
\text { (2) re-establishing social } \\
\text { networks; and (3) intimate } \\
\text { relationships. }\end{array}$ \\
\hline $\begin{array}{l}\text { Ottosson et al. } \\
\quad \text { (2013) [33] } \\
\text { Sweden }\end{array}$ & $\begin{array}{l}\text { To describe the experience of } \\
\text { food, eating, and meals } \\
\text { after radiotherapy treatment } \\
\text { for HNC }\end{array}$ & Qualitative & Interview & $\begin{array}{l}13 \text { patients with HNC (11 male and } \\
2 \text { female). Age range } 47-70 \\
\text { years. Treatment: RT only- } 6 \text {; } \\
\text { RT + surgery - } 7 \text {. }\end{array}$ & $\begin{array}{l}\text { Findings suggest six post-treatment } \\
\text { categories of patients' } \\
\text { experience: (1) a long journey; } \\
\text { (2) a new way of eating; (3) } \\
\text { eating without satisfaction; (4) } \\
\text { challenging meals outside the } \\
\text { family; (5) support and } \\
\text { information; and (6) a new } \\
\text { normal. }\end{array}$ \\
\hline $\begin{array}{l}\text { Parahoo et al. } \\
\text { (2019) [34] } \\
\text { Northern } \\
\text { Ireland }\end{array}$ & $\begin{array}{l}\text { To explore the experience of } \\
\text { dental loss in patients with } \\
\text { HNC }\end{array}$ & Qualitative & $\begin{array}{l}\text { Semi-structured } \\
\text { interview }\end{array}$ & $\begin{array}{l}15 \text { patients with HNC ( } 10 \text { male and } \\
5 \text { female). Age range } 51-80 \\
\text { years. Treatment: RT-2; RT + } \\
\text { CT-3; surgery + RT-7; } \\
\text { surgery + RT + CT }-2 \text {; surgery } \\
\text { only - } 1 \text {. }\end{array}$ & $\begin{array}{l}\text { Post-treatment experiences include } \\
\text { (1) impact of dental loss; (2) } \\
\text { coping with dental loss; and (3) } \\
\text { getting dentures and implants. }\end{array}$ \\
\hline $\begin{array}{l}\text { Pateman et al. } \\
\quad(2015)[35] \\
\text { Australia }\end{array}$ & $\begin{array}{l}\text { To describe how people with } \\
\text { HNC cope with altered oral } \\
\text { function and to identify } \\
\text { their supportive care needs }\end{array}$ & Qualitative & $\begin{array}{l}\text { Semi-structured } \\
\text { interview }\end{array}$ & $\begin{array}{l}6 \text { patients with HNC ( } 4 \text { male and } 2 \\
\text { female). Age range } 50-72 \text { years. } \\
\text { Treatment: RT + CT }-3 \text {; } \\
\text { surgery }-1 \text {; surgery + RT-2. }\end{array}$ & $\begin{array}{l}\text { Three key themes describing patient } \\
\text { experiences of altered oral } \\
\text { function: (1) dimensions of } \\
\text { eating; (2) maintaining oral } \\
\text { health; and (3) adapting to the } \\
\text { chronic side effects. }\end{array}$ \\
\hline $\begin{array}{l}\text { Patterson et al. } \\
\text { (2015) [36] } \\
\text { England }\end{array}$ & $\begin{array}{l}\text { To describe HNC patients' } \\
\text { experiences of change of } \\
\text { swallowing challenges } \\
\text { following } \\
\text { chemoradiotherapy }\end{array}$ & Qualitative & $\begin{array}{l}12 \text { patient } \\
\text { observations, } \\
4 \text { with partner } \\
\text { present. }\end{array}$ & $\begin{array}{l}\text { Phase 1: } 12 \text { patients with } \mathrm{HNC}(10 \\
\text { male and } 2 \text { female) and } 4 \\
\text { partners. Age range } 45-77 . \\
\text { Treatment: CT-10; RT-2. }\end{array}$ & $\begin{array}{l}\text { Findings include early } \\
\text { post-treatment and late } \\
\text { post-treatment experiences. } \\
\text { Eating and drinking issues are } \\
\text { highly individualised and have }\end{array}$ \\
\hline
\end{tabular}


Table 1 (continued)

\begin{tabular}{|c|c|c|c|c|c|}
\hline $\begin{array}{l}\text { Author(s), year } \\
\text { and country }\end{array}$ & Study aim & $\begin{array}{l}\text { Research } \\
\text { design }\end{array}$ & Data collection & Sample characteristics & Main study findings \\
\hline & & & $\begin{array}{l}6 \text { individual } \\
\text { interviews } \\
\text { and } 3 \text { dyad } \\
\text { interviews. }\end{array}$ & $\begin{array}{l}\text { Phase 2: } 9 \text { patients with } \mathrm{HNC}(8 \\
\text { male and } 1 \text { female) and } 3 \\
\text { partners. Age range } 50-72 \text { years. } \\
\text { Treatment: CT }-7 \text {; RT }-2 \text {. }\end{array}$ & $\begin{array}{l}\text { pervasive physical, social, and } \\
\text { practical aspects. }\end{array}$ \\
\hline $\begin{array}{l}\text { Semple et al. } \\
\quad(2019)[37] \\
\text { Northern } \\
\quad \text { Ireland }\end{array}$ & $\begin{array}{l}\text { To explore the long-term } \\
\text { impact of living with an } \\
\text { obturator to rehabilitate a } \\
\text { maxillary defect }\end{array}$ & Qualitative & $\begin{array}{l}\text { Semi-structured } \\
\text { interview }\end{array}$ & $\begin{array}{l}12 \text { patients with } \mathrm{HNC} \text { ( } 8 \text { male and } 4 \\
\text { female). Age range } 38-84 \text {. } \\
\text { Treatment: surgery only- } 7 \text {; } \\
\text { surgery + RT-4; surgery + RT } \\
+ \text { CT-1. }\end{array}$ & $\begin{array}{l}\text { The experience of living with an } \\
\text { obturator is demonstrated across } \\
\text { (1) preparedness for living with } \\
\text { an obturator; (2) impact of living } \\
\text { with an obturator; (3) stability } \\
\text { and retention of an obturator; and } \\
\text { (4) coping strategies. }\end{array}$ \\
\hline $\begin{array}{l}\text { Sterba et al. } \\
\quad(2017)[38] \\
\text { USA }\end{array}$ & $\begin{array}{l}\text { To characterise primary } \\
\text { end-of-treatment challenges } \\
\text { in HNC to assist the } \\
\text { development of a } \\
\text { survivorship needs } \\
\text { assessment planning tool }\end{array}$ & Qualitative & $\begin{array}{l}\text { Semi-structured } \\
\text { interview }\end{array}$ & $\begin{array}{l}17 \text { patients with } \mathrm{HNC} \text { ( } 10 \text { male and } \\
7 \text { female). Age range } 33-75 \\
\text { years. Treatment: surgery-82\%; } \\
\text { CT-59\%; RT-82\%. } \\
14 \text { caregivers ( } 6 \text { male and } 8 \text { female). } \\
\text { Age range } 29-83 \text {. }\end{array}$ & $\begin{array}{l}\text { The findings highlighted the } \\
\text { post-treatment physical, } \\
\text { emotional, and social challenges } \\
\text { and a wide variety of complex } \\
\text { follow-up care experiences and } \\
\text { testing of the Survivorship Needs } \\
\text { Assessment Planning (SNAP) } \\
\text { tool. }\end{array}$ \\
\hline $\begin{array}{l}\text { Tong et al. } \\
\text { (2011) [39] } \\
\text { Hong Kong }\end{array}$ & $\begin{array}{l}\text { To gain patients' perspectives } \\
\text { and experiences of } \\
\text { post-irradiation swallowing } \\
\text { difficulties }\end{array}$ & Mixed-methods & $\begin{array}{l}\text { Semi-structured } \\
\text { in-depth } \\
\text { interview and } \\
\text { self-report } \\
\text { questions }\end{array}$ & $\begin{array}{l}60 \text { with nasopharyngeal cancer ( } 42 \\
\text { male and } 18 \text { female). Age range } \\
34-71 \text { years. Treatment: RT- } \\
60 .\end{array}$ & $\begin{array}{l}\text { Post-irradiation experiences include } \\
\text { (1) patient judgement of } \\
\text { swallowing difficulties; (2) } \\
\text { definitions of a normal diet; (3) } \\
\text { the perceptions of 'no } \\
\text { difficulties'; and (4) little } \\
\text { attention paid to dysphagia } \\
\text { symptoms. }\end{array}$ \\
\hline $\begin{array}{l}\text { Zou et al. } \\
\qquad(2015)[40] \\
\text { China }\end{array}$ & $\begin{array}{l}\text { To understand how treatment } \\
\text { for tongue cancer affects } \\
\text { daily life at } 1 \text { year following } \\
\text { glossectomy with free flap } \\
\text { reconstruction }\end{array}$ & Qualitative & $\begin{array}{l}\text { Semi-structured } \\
\text { interview }\end{array}$ & $\begin{array}{l}16 \text { male patients with tongue } \\
\text { cancer. Age range } 34-64 \text { years. } \\
\text { Treatment: partial glossectomy } \\
\text { and free thigh flap } \\
\text { reconstruction-16. }\end{array}$ & $\begin{array}{l}\text { Patients described physical, social, } \\
\text { relational, and emotional } \\
\text { changes, change to sexual } \\
\text { practice, and use of traditional } \\
\text { Chinese medicine. }\end{array}$ \\
\hline
\end{tabular}

$R T$, radiotherapy; $C T$, chemotherapy; $P L$, palliative therapy

studies reported findings on patients' experiences of social eating and drinking after treatment for HNC.

\section{Participants}

Within the 24 included studies, a heterogenous HNC population of 516 patients (male $=379$, female $=137$ ) was identified. Sample sizes ranged from 6 to 135 . These included participants diagnosed across a range of tumour locations such as oral cavity, tonsil, larynx, and pharynx, of various stages and receiving different modalities of treatment. Twenty-one studies included patients from different HNC subsites. Three papers focused on patients with one type of HNC: oral cancer [24], tonsil cancer [29], tongue cancer [40]. Within the studies, the treatment a person received resulted in unique physical and functional effects, both in the acute and long-term recovery that impacted social eating and drinking. Some patients living with an obturator following a maxillectomy experienced nasal leakage and altered chewing [37], whereas dental loss often contributed to issues with biting, swallowing, and talking [34]. Partial glossectomy frequently led to limited tongue mobility [40], and a common side effect following radiotherapy was xerostomia [32]. Other functional challenges that directly impacted on HNC patients' ability to participate in social eating and drinking activities were coughing [20, 22, 33], noise from eating and swallowing [28], swallowing difficulties $[30,35,39]$, and oral incontinence [20, 37]. The physical and functional challenges people encountered with eating and drinking led to an altered eating experience [18].

\section{Results of synthesis}

Two themes were developed to illustrate the reported social eating and drinking experiences for patients with HNC: (1) the experience of loss associated with social eating and drinking and (2) adjusting and support to promote social eating and drinking.

\section{Theme 1: The experience of loss associated with social eating and drinking}

Physical alterations for patients with $\mathrm{HNC}$ had significant repercussions on their ability, perceived ability, and confidence 
to engage in social activities involving food and eating. Patients regarded their experience of social eating as a loss. The experience of loss is depicted across three subthemes: (1) loss of ability and confidence to eat in a socially acceptable way, (2) loss of social participation and enjoyment associated with normal eating and drinking, and (3) loss of togetherness with family and friends. For the context of this review, social eating refers to both eating and drinking.

Theme 1.1: Loss of ability and confidence to eat and drink in a socially acceptable way The effects of HNC and the impact of treatment regularly prevented people from sharing meals in a social situation $[25,26,35]$. Often, patients perceived they had lost the ability to eat and drink with others in a socially acceptable way. Patients felt embarrassment, shame, and were self-conscious about not being able to control their physical symptoms, such as drooling and nasal leakage; highlighting how this led to 'making a mess' in social situations $[18,21$, $22,28,33,35-37]$. Selecting food to eat became a conscientious process, and patients felt unable to eat like a 'normal' person $[22,24,30]$. Occasionally patients became anxious when they were invited to someone's house. They had a fear of insulting the host if they were unable to eat the food being served but also did not want attention drawn to the situation, with a 'fuss' being made over not being able to eat or drink $[25,33,36]$.

\section{Theme 1.2: Experiencing loss of participation and enjoyment} associated with social eating and drinking Participants reported eating less regularly with others after their treatment and for some, this was such a challenge that they excluded themselves from social occasions and chose to remain at home [21, 25, 26]. Meeting with friends and family in restaurants or cafés became a less common occurrence [22, 28, 36]. Patients reported that they refrained from attending special celebrations, such as weddings [34, 36, 37], Christmas [37], and New Year parties [25] due to the functional and psychological challenges of eating and drinking. This sometimes extended to the type of holidays people were able to take [30]. Not participating in social eating activities restricted patient's social lives and often isolated them from others $[35,36]$.

Some patients, however, who attended social eating events appeared to not have the same sense of enjoyment as before treatment and believed that they no longer made the same contribution to the social environment [22, 27, 40]. For example, residual impairment meant that people were unable to talk and eat at the same time, which made engaging in mealtime conversation more arduous [22-27]. Additionally, the noisy surroundings in restaurants were not conducive to conversation and therefore required more effort to participate [19, 20]. The uncertainty of the availability of suitable food resulted in diminished enjoyment when eating out, and participants regarded this as a loss $[20,32,39]$. The loss of social participation was not solely limited to going out of the house to eat and drink but also impacted mealtime participation at home.

Theme 1.3: Experiencing loss of togetherness with family and friends The findings demonstrated that following $\mathrm{HNC}$ treatment, patients shared meals less frequently with family and friends, which had an impact on relationships. Regular meals at home were no longer shared as a family, and patients ate separately as family members felt guilty or uncomfortable enjoying a meal that the person could not share [18, 30, 38]. Consequently, patients experienced a loss of togetherness with their friends and family [30]. Family members became irritated at the length of time it took to eat a meal, which affected their relationship [39]. The process of eating often required more time which could result in the patient remaining at the table alone to finish their meal and consequently feeling more isolated $[28,33,39]$. Some patients indicated that they no longer received invitations to social events from friends or family members, as eating would be involved [23]. For this reason, patients reported to be less motivated to socialise with others [28]. The loss of togetherness extended from friends, family, spanning to work colleagues [37].

\section{Theme 2: Adjusting and coping to promote social eating}

Despite the challenges and the associated losses caused by HNC treatment, over time, many patients found methods of adjusting and adapting to enable coping with social eating [40]. Some of the coping strategies demonstrated by patients, such as avoidance and isolation limited their participation in social eating opportunities [25, 37]; however, alternative methods of adapting facilitated positive participation with eating socially. By adopting adjustment strategies, some people were able to reduce social embarrassment and disruptions to their social eating [40]. This was demonstrated by the two themes: (1) taking control of the social eating situation and (2) engaging with support.

Theme 2.1: Taking control of the social eating situation Being candid about their cancer and describing how the disease affected their eating and drinking helped demonstrated ownership over their situation [22]. When going to restaurants, some patients would ask for discrete places to sit to be able to eat more privately and feel less conspicuous [22, 36, 37]. Others contacted restaurants in advance to ensure there would be food that they would be able to eat [35]. This extended to going on holidays where they could ensure food preparation met their individual needs. Cruises appeared to be a good option [30]. Food modification was a crucial aspect of coping with social eating and drinking challenges. Smaller, more comfortable to swallow foods were prepared to control symptoms or finish at the same time as others $[23,26]$. Sometimes, more palatable 
food would have been requested; less spicy, dry, or acidic [22, 23]. Alternatively, bringing their own supply of items such as custards, sauces, and gravies to modify meals made food more manageable in restaurants $[31,33]$. To participate socially, on occasions, patients had to choose less appetising options [23].

At social gatherings, some patients would eat alone or requested family members to eat before them [36, 37]. Alternatively, some patients would eat in their own homes prior to meeting friends or family. This ensured they could eat their food but still participate and gain value from spending time with those in their social network [22,37]. Others would choose to invite friends and family to their house instead of going out in order to take control of the food that was available [34].

Theme 2.2: Engaging with support Whilst patients demonstrated a range of strategies in which they employed to cope with the physiological, psychological, and social aspects of eating, support from family and friends was paramount. In these circumstances, friends and family were generally described as supportive, helpful, and encouraging [22]. Some ways family members were able to support people included adapting meals, cooking alternative meals, and the alteration of eating patterns by the patient's spouse [22, 30].

Following treatment some individuals reported feeling a sense of security when eating with family and close friends, as this alleviated stress and promoted confidence at mealtimes $[22,33]$. For parents of young children, mealtimes were a positive experience as they were cooking, feeding or entertaining the children, which provided a sense of purpose and meaning [36].

There was little evidence of support received from HCPs to help promote patients' experience of social eating. There were some indications of how HCPs could respond to the social eating challenges for people living with and beyond $\mathrm{HNC}$. These included adopting holistic approaches providing education beyond the physical side effects of functional challenges and nutritional status of food items throughout the trajectory of recovery $[22,31,34]$.

\section{Discussion}

This is the first systematic review synthesising the social eating and drinking experiences for patients following treatment for HNC. The findings articulate an array of essential losses for patients following $\mathrm{HNC}$, including a loss of confidence to eat socially, loss of taking part in social events, and loss of family togetherness. This review identified that patients were more likely to seek and receive support from someone within their close social network, rather than an HCP. The essential role of family during recovery and in cancer survivorship is highlighted. This body of literature primarily demonstrates the challenges associated with social eating and drinking after $\mathrm{HNC}$ treatment, with minimal findings on strategies to positively promote eating socially representing a gap in the current evidence-base.

Within the findings, it was reported that the social network with whom patients ate changed after treatment. Unfortunately, for some patients, mealtimes were no longer a social occasion and was viewed as a significant loss [44]. Eating was missed because of the taste and flavour of food; however, people chiefly mourned the loss of inclusion and belonging that food brings, including cultural and personal identity [18]. Challenges with social eating can inhibit the meaning of meals and restrict family togetherness within the home $[44,45]$. There is a potential risk of reduced quality of life for patients with $\mathrm{HNC}$ who have challenges with eating and drinking. The functional challenges of HNC treatment and lack of social integration place people at risk of social isolation, loneliness, and poorer health-related quality of life $[46,47]$.

Wittmann et al. [48] described the interconnected biopsychosocial losses and successive feelings of grief in patients and partners after treatment for cancer. In viewing social eating and drinking challenges as a process of grief as opposed to a one-time event, it reframes the concept as an area that requires ongoing acknowledgement and potential continued support. Patients undergoing treatment for HNC may not be fully prepared or anticipate the ongoing functional challenges resulting from treatment [37]. For many patients, functional side effects can improve over time, however for some, it is slow, and for others, they never regain pre-treatment function $[49,50]$. Social eating can continue to be a problem beyond 12 months post-treatment and a contributing factor to overall inferior quality of life [51]. Living with cancer as a chronic illness is a life-long process that requires adaption and change [52]. Some patients may come to the point of acceptance; however, additional research should examine the change of perception and experience of social eating across the trajectory from diagnosis to acute and long-term recovery.

An assessment tool developed by Burges-Watson et al. [18] provides a holistic framework of assessment for patients with altered eating challenges, recognising the biological causes, psychological consequences, and social impact. As there are a wide variety of activities associated with eating and drinking, HCPs must ensure eating and drinking needs of patients are explored beyond the physical domains. Patients reported a range of emotional reactions relating to social eating such as frustration, irritation, and anxiety. However, there is a paucity of information on how people coped with any emotional pain. Given the biopsychosocial challenges that accompany eating and drinking with others, a multi-disciplinary approach is required to ensure support extends beyond the mechanical and functional tasks of eating and drinking. Future research must consider how people cope 
beyond the physical and practical adjustments that they make, investigating the psychological, emotional, and relational domains.

Families are at the core of social eating and the key support providers for people with HNC [1]. Despite, sometimes feeling misunderstood, the assistance of family and friends was invaluable to overcoming social eating challenges and often the primary source for patients to seek support $[46,53]$. As close relationships appear to be the most important means of support, it is essential to explore and understand the experience of family and close friends. Strategies for communal coping should be developed as both members of a relationship are involved with managing chronic illness [54]. Existing research by Patterson et al. [45] and Nund et al. (C) [55] explicitly investigate the experiences of family members of people with social eating challenges after treatment for $\mathrm{HNC}$ and conclude the potential burden of caring for someone with functional eating and drinking challenges. The need for feasible and acceptable family-based interventions has been previously indicated [56].

Given the wide-ranging impact of altered eating and drinking, it is imperative that studies investigate possible interventions that provide meaningful approaches to facilitate positive social participation in eating and drinking environments for patients and family members. Whittemore and Dixon [57] suggested that the key to managing a chronic illness is selfintegration. Whilst coping, integration, and adjustment were demonstrated by participants in these findings, there was little detail on the process of acceptance or self-management. Recent work by Dunne et al. [21] provides evidence of incorporating self-management strategies into HNC survivorship programmes. Part of this process includes trial and error techniques [34], goal setting [52], and incorporation of selfmanagement strategies [21]. As Dunne [21] reported that self-management works best in the context of individualised approaches. As people, cancers and treatments are different, patients may benefit from having interventions provided at different times, where short- and long-term interventions are used to complement each other [52].

Within the literature, there are no findings on the social experiences for people with $\mathrm{HNC}$ who require temporary or permanent nutrition via a tube, for example, a percutaneous endoscopic gastrostomy (PEG) or radiologically inserted gastrostomy (RIG). Further research is necessary for patients who are likely to have exacerbated challenges from specific treatments and have particular functional challenges such as laryngectomies, tracheostomies, and glossectomies.

\section{Limitations}

No studies in this review had a specific aim to explore social eating experiences. Information on this topic was noted during the reporting of other topics, but the phenomenon of social eating and drinking was not explored in depth. The findings of this review did not differentiate the type or location of cancer or the treatment each person received. Further research is required to investigate the unique social eating challenges related to treatment modality or HNC subsite. Quality assessment was completed, but no study was rejected due to the quality of methodology. However, all the included papers had a score between 6 and 9 in the CASP tool, indicating that these were moderate to high-quality studies. The initial process of identifying literature was completed by the first author and the process checked by the research team. To enhance rigour, this process would have been completed independently by an additional researcher.

\section{Conclusion}

The physical side effects of treatment for patients with HNC impact functional eating and drinking abilities in acute and long-term recovery. This affects both a person's ability and confidence to eat and drink in front of others, thus leading to important losses in their life. These losses have emotional, relational, and cultural significance. Many people with HNC demonstrated resilience and overcame barriers by adapting and coping with eating and drinking socially, with support from family and friends being pivotal. Family- or coupleorientated resources should be developed to provide support to the person with $\mathrm{HNC}$ and their close family.

Supplementary Information The online version contains supplementary material available at https://doi.org/10.1007/s00520-021-06062-7.

Acknowledgements The authors would like to thank Kelly McCoo for her support and guidance in conducting the database searches and the internal peer reviewers for their time and comments on the review.

Code availability N/A

Author contribution N/A

Funding This review was undertaken as part of a $\mathrm{PhD}$ studentship at Ulster University (MD) and funded by the Department for the Economy (DfE) Studentship.

Data Availability This is a systematic review of previously published data. Data has been referenced and attributed to its source within the review.

\section{Declarations}

Ethics approval N/A

Consent to participate N/A 
Consent for publication N/A

Conflict of interest The authors declare no competing interests.

Open Access This article is licensed under a Creative Commons Attribution 4.0 International License, which permits use, sharing, adaptation, distribution and reproduction in any medium or format, as long as you give appropriate credit to the original author(s) and the source, provide a link to the Creative Commons licence, and indicate if changes were made. The images or other third party material in this article are included in the article's Creative Commons licence, unless indicated otherwise in a credit line to the material. If material is not included in the article's Creative Commons licence and your intended use is not permitted by statutory regulation or exceeds the permitted use, you will need to obtain permission directly from the copyright holder. To view a copy of this licence, visit http://creativecommons.org/licenses/by/4.0/.

\section{References}

1. Sobal J, Nelson M (2003) Commensal eating patterns: a community study. Appetite. 41(2):181-190. https://doi.org/10.1016/s01956663(03)00078-3

2. Phull S, Wills W, Dickinson A (2015) Is it a pleasure eating together? Theoretical reflections on convivality and the Mediterranean diet. Sociol Compass 9(11):977-986. https://doi.org/10.1111/ soc4.12307

3. Fischler C (2011) Commensality, society and culture. Soc Sci Inf 50(3-4):528-548. https://doi.org/10.1177/0539018411413963

4. Dunbar RIM (2017) Breaking bread: the functions of social eating. Adapt Hum Behav Physiol 3:198-211. https://doi.org/10.1007/ s40750-017-0061-4

5. Motteli S, Siegrist M, Keller C (2017) Women's social eating environment and its associations with dietary behavior and weight management. Appetite. 110:86-93. https://doi.org/10.1016/j. appet.2016.12.014

6. Absolom S, Roberts A (2011) Connecting with others: the meaning of social eating as an everyday occupation for young people. $\mathrm{J}$ Occup Sci 18(4):339-349. https://doi.org/10.1080/14427591. 2011.586324

7. Rosin P (2005) The meaning of food in our lives: a cross-cultural perspective on eating and well-being. J Nutr Educ Behav 37(S2): S107-S112. https://doi.org/10.1016/s1499-4046(06)60209-1

8. Vesnaver E, Keller H (2011) Social influences and eating behavior in later life: a review. J Nutr Gerontol Geriatr 30(1):2-23. https:// doi.org/10.1080/01639366.2011.545038

9. Bennell J, Taylor C (2013) A loss of social eating the experience of individuals living with gastroparesis. J Clin Nurs 22(19-20):28122821. https://doi.org/10.1111/jocn.12196

10. Rathod S, Livergant J, Klein J, Witterick I, Ringash J (2015) A systematic review of quality of life in head and neck cancer treated with surgery with or without adjuvant treatment. Oral Oncol 51(10):888-900. https://doi.org/10.1016/j.oraloncology.2015.07. 002

11. Chan KMK, Chan HKW, Siu JYL, Nund RL, Ward EC (2018) Impact of head and neck cancer treatment on survivors' mealtime experience. Laryngoscope. 129(7):1572-1578. https://doi.org/10. 1002/lary.27501

12. Crowder S, Douglas K, Pepino MY, Sarma KP, Arthur AE (2018) Nutrition impact symptoms and associated outcomes in postchemoradiotherapy head and neck cancer survivors: a systematic review. J Cancer Surviv 12:479-494. https://doi.org/10.1007/ s11764-018-0687-7
13. Porto de Toledo I, Pantoja LLQ, Luchesi KF, Assad DX, Canto G, Guerra ENS (2019) Deglutition disorders as a consequence of head and neck cancer therapies: a systematic review and meta-analysis. Support Care Cancer 27:3681-3700. https://doi.org/10.1007/ s00520-019-04920-z

14. Ganzer H, Touger-D R, Byham-Gray L, Murphy BA, Epstein JB (2015) The eating experience after treatment for head and neck cancer: A review of the literature. Oral Oncol 51(7):634-642. https://doi.org/10.1016/j.oraloncology.2015.04.014

15. Bressan V, Bagnasco A, Aleo G, Cantania G, Zanini MP, Timmins F, Sasso L (2017) The life experience of nutrition impact symptoms during treatment for head and neck cancer patients: a systematic review and meta-synthesis. Support Care Cancer 25:1699-1712. https://doi.org/10.1007/s00520-017-3618-7

16. Moher D, Liberati A, Tetzlaff J, Altman D (2009) Preferred reporting items for systematic reviews and meta-analyses: the PRISMA statement. Ann Intern Med 151(4):264-269. https://doi. org/10.7326/0003-4819-151-4-200908180-00135

17. Alberda C, Alvadj-Korenic T, Mayan M, Gramlich L (2017) Nutrition care in patients with head and neck or esophageal cancer: the patient perspective. Nutr Clin Pract 32(5):664-674. https://doi. org/10.1002/ncp.10190

18. Burges-Watson DL, Lewis S, Bryant V, Patterson J, Kelly C, Edwards-Stuart E, Murtagh M, Deary V (2018) Altered eating: a definition and framework for assessment and intervention. BMC Nutr 4(14). https://doi.org/10.1186/s40795-018-0221-3

19. Checklin M, Bain J, Bath L, Lethbridge K (2019) Patients' perspectives on what makes a better care experience while undergoing treatment for oropharyngeal dysphagia secondary to head and neck cancer. Dysphagia. 35(4):702-716. https://doi.org/10.1007/ s00455-019-10077-y

20. Dooks P, McQuestion M, Goldstein D, Molassiotis A (2012) Experiences of patients with laryngectomies as they reintegrate into their community. Support Care Cancer 20:489-498. https://doi.org/ 10.1007/s00520-011-1101-4

21. Dunne S, Coffey L, Sharp L, Desmond D, Gooberman-Hill R, O'Sullivan E, Timmons A, Keogh I, Timon C, Gallagher P (2017) Integrating self-management into daily life following primary treatment: head and neck cancer survivors' perspectives. J Cancer Surviv 13:43-55. https://doi.org/10.1007/s11764-0180726-4

22. Einarsson S, Laurell G, Ehrsson YT (2019) Experiences and coping strategies related to food and eating up to two years after the termination of treatment in patients with head and neck cancer. Eur J Cancer Care 28:e12964. https://doi.org/10.1111/ecc.12964

23. Ganzer H, Rothpletz-Puglia P, Byham-Gray L, Murphy BA, Touger-Decker R (2015) 'The eating experiences in long-term survivors of head and neck cancer: a mixed methods study. J Cancer Surviv 23:3257-3268. https://doi.org/10.1007/s11764-019-007982

24. Goswami S, Gupta SS (2019) How patients of oral cancer cope up with impact of the disease? A qualitative study in Central India. Indian J Palliat Care 25(1):103-109. https://doi.org/10.4103/IJPC. IJPC_118_18

25. Jiang N, Zhao Y, Jansson H, Chen X, Martensson J (2017) Experiences of xerostomia after radiotherapy in patients with head and neck cancer: a qualitative study. J Clin Nurs 27:e100-e108. https://doi.org/10.1111/jocn.13879

26. McQuestion M, Fitch M, Howell D (2011) The changed meaning of food: physical, social and emotional loss for patients having received radiation treatment for head and neck cancer. Eur $\mathrm{J}$ Oncol Nurs 15(2):145-151. https://doi.org/10.1016/j.ejon.2010. 07.006

27. Molassiotis A, Rogers M (2012) Symptom experience and regaining normality in the first year following a diagnosis of head and neck cancer: a qualitative longitudinal study. Palliat Support 
Care 10(3):197-204. https://doi.org/10.1017/ S147895151200020X

28. Moore KA, Ford PJ, Farah CS (2014) "I have quality of life... but...": exploring support needs important to quality of life in head and neck cancer. Eur J Oncol Nurs 18(2):192-200. https://doi.org/ 10.1016/j.ejon.2013.10.010

29. Mortensen GL, Paaske PB (2012) Patients perceive tonsil cancer as a strike at psycho-socially "vital organs". Dan Med J 59(9):A4504

30. Nund RL, Ward EC, Scarinci NA, Cartmill B, Kuipers P, Porceddu SV (2014) The lived experience of dysphagia following nonsurgical treatment for head and neck cancer. Int J Speech Lang Pathol 16(3):282-289. https://doi.org/10.3109/17549507.2013. 861869

31. Nund RL, Ward EC, Scarinci NA, Cartmill B, Kuipers P, Porceddu SV (2014) Survivors' experiences of dysphagia-related services following head and neck cancer: implications for clinical practice. Int J Lang Commun Disord 49(3):354-363. https://doi.org/10. 1111/1460-6984.12071

32. O'Brien K, Roe B, Low C, Deyn L, Rogers SN (2012) An exploration of the perceived changes in intimacy of patients' relationships following head and neck cancer. J Clin Nurs 21(17-18): 2499-2508. https://doi.org/10.1111/j.1365-2702.2012.04162.x

33. Ottosson S, Laurell G, Olsson C (2013) The experience of food, eating and meals following radiotherapy for head and neck cancer: a qualitative survey. J Clin Nurs 22(7-8):1034-1043. https:/doi. org/10.1111/jocn.12151

34. Parahoo RS, Semple CJ, Killough S, McCaughan E (2019) The experience among patients with multiple dental loss as a consequence of treatment for head and neck cancer: a qualitative study. J Dent 82:30-37. https://doi.org/10.1016/j.jdent.2019.01.010

35. Pateman KA, Ford PJ, Batstone MD, Farah CS (2015) Coping with an altered mouth and perceived supportive care needs following head and neck cancer treatment. Support Care Cancer 23(8): 2365-2373. https://doi.org/10.1007/s00520-015-2607-y

36. Patterson JM, McColl E, Wilson J, Carding P, Rapley T (2015) Head and neck cancer patients' perceptions of swallowing following chemoradiotherapy. Support Care Cancer 23(12):3531-3538. https://doi.org/10.1007/s00520-015-2715-8

37. Semple CJ, Rutherford H, Killough S, Moore C, McKenna G (2019) Long-term impact of living with an obturator following a maxillectomy: a qualitative study. J Dent. https://doi.org/10.1016/j. jdent.2019.103212

38. Sterba KR, Zapla J, LaPelle N, Garris TK, Buchanan A, Scallion M, Day T (2017) Development of a survivorship needs assessment planning tool for head and neck cancer survivors and their caregivers: a preliminary study. J Cancer Surviv 11(6):822-832. https:// doi.org/10.1007/s11764-017-0621-4

39. Tong MCF, Lee KYS, Yuen MTY, Lo PSY (2011) Perceptions and experiences of post-irradiation swallowing difficulties in nasopharyngeal cancer survivors. Eur J Cancer Care 20(2):170-178. https:// doi.org/10.1111/j.1365-2354.2010.01183.x

40. Zou Y, Li Y, Zhou X, Yu J, Xie Y, Li L, Ouyang C, Li Z, Gu M, Hicks E, Maliski S (2015) Chinese tongue cancer survivors' perspectives one year post-partial glossectomy. Int J Nurs 4(1):34-43

41. Thomas J, Harden A (2008) Methods for the thematic synthesis of qualitative research in systematic reviews. BMC Med Res Methodol 8(45). https://doi.org/10.1186/1471-2288-8-45

42. Critical Appraisal Skills Programme (2019). CASP qualitative studies checklist. [online] Available at: https://casp-uk.net/casp-toolschecklists. Accessed: 1st February 2020

43. Long H, French D, Brooks J (2020) Optimising the value of the Critical Appraisal Skills Programme (CASP) tool for quality appraisal in qualitative evidence synthesis. Res Methods Med Health Sci 1(1):31-42. https://doi.org/10.1177/2632084320947559
44. Lang H, France F, Williams B, Humphris G, Wells M (2013) The psychological experience of living with head and neck cancer: a systematic review and meta-synthesis. Psychooncology. 22(12): 2648-2663. https://doi.org/10.1002/pon.3343

45. Patterson JM, Rapley T, Carding PN, Wilson JA, McColl E (2013) Head and neck cancer and dysphagia; caring for carers. Psychooncology. 22(8):1815-1820. https://doi.org/10.1002/pon. 3226

46. List MA, Rutherford JL, Stracks J, Haraf D, Kies MS, Vokes EE (2002) An exploration of the pretreatment coping strategies of patients with carcinoma of the head and neck. Cancer. 95(1):98-104. https://doi.org/10.1002/cncr.10653

47. Drageset S, Lindstrom TC, Underlid K (2016) "I just have to move on": women's coping experiences and reflections following their first year after primary breast cancer surgery. Eur J Oncol Nurs 21: 205-211. https://doi.org/10.1016/j.ejon.2015.10.005

48. Wittmann D, Carolan M, Given B, Palapattu G, Clark P, Montie J (2015) What couples say about their recovery of sexual intimacy after prostatectomy: toward the development of a conceptual model of couples' sexual recovery after surgery for prostate cancer. J Sex Med 12(2):494-504. https://doi.org/10.1111/jsm.12732

49. Cartmill B, Cornwell P, Ward E, Davidson W, Porceddu S (2012) Long-term functional outcomes and patient perspective following altered fractionation radiotherapy with concomitant boost for oropharyngeal cancer. Dysphagia. 27:481-490. https://doi.org/10. 1007/s00455-012-9394-0

50. Isaksson J, Salander P, Lilliehorn S, Laurell G (2016) Living an everyday life with head and neck cancer 2-2.5 years post-diagnosis - a qualitative prospective study of 56 patients. Soc Sci Med 154: 54-61. https://doi.org/10.1016/j.socscimed.2016.02.031

51. So WKW, Chan RJ, Chan DNS, Hughes BGM, Chair SY, Choi KC, Chan CWH (2012) Quality-of-life among head and neck cancer survivors at one year after treatment - a systematic review. Eur J Cancer 48(15):2391-2408. https://doi.org/10.1016/j.ejca.2012.04. 005

52. Naus MJ, Ishler MD, Parrott CE, Kovacs SA (2009) Cancer survivor adaptation model: conceptualizing cancer as a chronic illness. J Clin Psychol 65(12):1350-1359. https://doi.org/10.1002/jclp. 20622

53. Kristensen MB, Mikkelsen TB, Beck AM, Zwisler A, Wessel I, Diepernek KB (2019) To eat is to practice - managing eating problems after head and neck cancer. J Cancer Surviv 13(5):792-803. https://doi.org/10.1007/s11764-019-00798-2

54. Helgeson VS, Jakubiak B, Van Vleet M, Zajdel M (2017) Communal coping and adjustment to chronic illness: theory update and evidence. Personal Soc Psychol Rev 22(2):170-195. https:// doi.org/10.1177/1088868317735767

55. Nund RL, Ward EC, Scarinci NA, Cartmill B, Kuipers P, Porceddu SV (2014) [C] Carers' experiences of dysphagia in people treated for head and neck cancer: a qualitative study. Dysphagia 29:450458. https://doi.org/10.1007/s00455-014-9527-8

56. Ostroff J, Ross S, Steinglass P, Ronis-tobin V, Singh B (2004) Interest in and barriers to participation in multiple family groups among head and neck cancer survivors and their primary family caregivers. Fam Process 43(2):195-208. https://doi.org/10.1111/j. 1545-5300.2004.04302005.x

57. Whittemore R, Dixon J (2008) Chronic illness: the process of integration. J Clin Nurs 17(7b):177-187. https://doi.org/10.1111/j. 1365-2702.2007.02244.x

Publisher's note Springer Nature remains neutral with regard to jurisdictional claims in published maps and institutional affiliations. 